Pak. j. sci. ind. res. Ser. B: biol. sci. 2021 64B(1) 55-63

\title{
Estimation of Heavy Metals and Associated Health Risk in Selected Vegetables Grown in Peri-Urban Areas of Multan and Rawalpindi, Pakistan
}

\author{
Syed Abdul Wadood ${ }^{\text {a,bd*, Mian Kamran Sharif }}{ }^{\mathrm{a}}$, Muhammad Nadeem Ashraf ${ }^{\mathrm{c}}$, Rebia Ejaz ${ }^{\mathrm{a}}$, \\ Ghazala Kosar $^{a}$, Muhammad Azeem ${ }^{a}$ and Ghulam Murtaza ${ }^{a}$ \\ National Institute of Food Science and Technology, Faculty of Fog d Nutrition and Home Sciences, \\ ${ }^{b}$ Institute of Food Science and Technology CAAS/Key Laboratory of Agro-Products Processing, \\ Ministry of Agriculture Beijing, China \\ ${ }^{c}$ Institute of Soil and Environmental Sciences, University of Agriculture, Faisalabad, Pakistan \\ ${ }^{\mathrm{d} K e y ~ L a b o r a t a r y}$ of Agro Products Processing, Institute of Food Science, Chinese Academy of \\ Agriculture Sciences No. 1, Nongda South Road, Xi Beiwaug Haidian Distirct, China
}

(received January 8, 2018; revised April 2, 2018; accepted December 6, 2018)

\begin{abstract}
Food security is a serious issue in developing countries like Pakistan because of ever-increasing population. To feed the hunger population, safe and nutritious vegetables are growing concern as they are being polluted by heavy metals. The present study was conducted to investigate the concentration of heavy metals such as cadmium $(\mathrm{Cd})$, chromium $(\mathrm{Cr})$, lead $(\mathrm{Pb})$, nickel $(\mathrm{Ni})$, iron $(\mathrm{Fe})$, manganese $(\mathrm{Mn})$, and zinc $(\mathrm{Zn})$ in highly consumed vegetable collected from peri-urban markets of Rawalpindi and Multan region. Health risk associated with the consumption of these vegetables in term of estimated daily intake of metals (EDIM) and health risk index (HRI) was also evaluated among local consumers. Results showed that mean values of cadmium $(\mathrm{Cd})$, and lead $(\mathrm{Pb})$ in all vegetable samples from both region were exceeding the respective MAL set by FAO/WHO. Estimated daily intake of heavy metals was found below than the permissible limit. EDIM showed following decreasing trend $\mathrm{Fe}>\mathrm{Zn}>\mathrm{Mn}$ $>\mathrm{Ni}>\mathrm{Pb}>\mathrm{Cr}$ and $\mathrm{Cd}$, respectively. The health risk index (HRI) for all heavy metals were less than the threshold level (1), indicating no significant threat to the local population through the consumption of these vegetables.
\end{abstract}

Keywords: food safety, EDIM, HRI, Pakistan

\section{Introduction}

Vegetables are a vital part of our diet and are known as an inexpensive. Pakistan is producing a variety of vegetables to satisfy local as well as international demand. Being agro-based economy about $70 \%$ of our population is directly or indirectly associated with this sector. The total area under vegetable cultivation is about $2 \%$ of the total crop production, while the export share is very low $0.22 \%$ GOP (2013). Vegetables are very rich sources of important biochemical and nutrients like carotene, carbohydrates, calcium, iron, ascorbic acid and extensive concentration of trace minerals Jimoh and Oladiji (2005). These are the basic sources of energy, especially in poor countries. The minimum daily consumption of fruits and vegetables should be more than $400 \mathrm{~g}$ per person as described by World Health

*Author for correspondence;

E-mail: wadoodabdu1999@gmail.com
Organization (WHO) in order to get numerous nutrients for optimum health studied by Lock et al. (2005). In Pakistan per capita daily intake of vegetable is $134 \mathrm{~g}$ which is $66.5 \%$ below than the minimum recommended levels of $400 \mathrm{~g}$ per day GOP (2013).

Food safety is the key issue, especially in the developing countries. Production of the safe food is a big challenge and an important aspect of food quality assurance as well as public health. Generally, fruits and vegetables are irrigated with groundwater and other freshwater reservoirs. However, due to water scarcity in developing countries the reliance on groundwater has increased which is usually expensive and also poor in quality due to sodium adsorption, high electrical conductivity, sodium carbonate residues, and heavy metals Murtaza et al. (2008). Furthermore, domestic wastewater and industrial effluents have become an alternate source of irrigation, especially in the Peri-Urban areas. In 
developing countries, approximately $80 \%$ of the wastewater generated is estimated to be used to irrigate crops without prior treatment which is describe by Ensink et al. (2004). In Pakistan, approximately 30\% of wastewater is used for irrigation, while rest of water is discharged into rivers without any treatment FAO (2002). The use of wastewater for irrigation purpose is controversial due to associated benefits and health concerns. Wastewater application has several disadvantages including the groundwater contamination, addition of heavy metals and organics in the soil resulting in a favourable environment for the growth of harmful micro-organisms Mapanda et al. (2007)

Dietary revelations to toxic metals (lead, cadmium and copper) and metalloid (arsenic) have been known as a danger to human health through the intake of different vegetables. This condition results in uneven degrees of health complications depending on the degree of exposures Demirezen and Aksoy (2006). Furthermore, the contaminated food intake with heavy metals can seriously decarease in immunological defences of malnutrition related disabilities, intrauterine growth retardation and a high incidence of upper gastrointestinal cancer (Zakir et al., 2009; Khan et al., 2008; Muchuweti et al., 2006). In addition, such metals like iron (Fe), zinc $(\mathrm{Zn})$, copper $(\mathrm{Cu})$ and manganese $(\mathrm{Mn})$ require in small amount and known as trace elements. Among these, zinc and copper are essential for vital physiological and biochemical roles and necessary for sustaining health throughout the life. In developing countries, prompt and un-organized urbanization and industrialization have contributed to the high level of heavy metals in the urban environment (Wong et al., 2003). Heavy metals are persistent and nonbiodegradable environmental pollutants which may be dumped on the surfaces of crop and later diffused into the tissues of the plants. In some areas, contamination of water by heavy metals is almost unavoidable because of the natural process (weathering of rocks) and human activities (domestic, agricultural and industrial effluents). Wastewater from the industries of electroplating, paint, mining or chemical laboratories frequently contains a high concentration of heavy metals including lead, cadmium and copper studies Raouf and Raheim (2016). These elements at above concentration not only could manage toxic effect in vegetables but also enter to the food chain, get bio-magnified and pose a significant threat to human health by Haiyan and Stuanes (2003). Application of wastewater for crop cultivation is known as an important source of heavy metals in soil Mapanda et al. (2005). Excessive level of metals in vegetables is specified due to use of untreated wastewater for a long time (Sharma et al., 2008). The presence of metallic compounds in fertilizers impart an extra source of metal contamination for vegetables (Yusuf et al., 2003). Atmospheric uptake of heavy metals from gas emission has also been known to contribute heavy metal pollution in vegetable crops Wiinikka et al. (2013).

The Pakistani population is increasingly growing leading to an immense demand for food to eat its needs. Most farmers are also illiterate and are unaware of the nonjudicial use of agrochemicals. Pakistan is one of the leading country in which agrochemicals are widely used to increase their production. The frequent application of agrochemicals also contaminated the soil and water sources. Ultimatitly, these residues pave the way in the human body through oral, dermal and inhalation. The recent advances in the analytical chemistry have made it possible to even detect the traces of these toxic elements resulting in serious threat to the export of fruits and vegetables to the technically advanced countries in WTO scenario. This situation demands screening of locally produced vegetables for heavy metals as well as other toxins not only for export purpose but also for the safeguard of the human health. The aim of this study was to investigate the heavy metals concentration in highly consumed vegetables grown in Peri-Urban areas of two major divisions of Punjab and also evaluate their associated health risk among the local population. To the best of our knowledge, no or very few studies of this kind had been reported in the proposed study location with rarely focusing potential health risks of heavy metals exposure.

\section{Materials and Methods}

Procurement of raw material. Total of 51 vegetables samples i.e. potato (Solanum tuberosum), onion (Allium cepa), carrot (Daucus carota), turnip (Brassica rapa), cucumber (Cucumis sativus), tomato (Solanum lycopersicum), cauliflower (Brassica oleracea), pea (Pisum sativum), brinjal (Solanum melongena), bitter gourd (Momordica charantia), round gourd (Praecitrullus fistulosus), and okra (Aesculantus malvaceae) were collected from six Peri-Urban markets of two regions i.e. Multan and Rawalpindi, Punjab, Pakistan. The samples were packed into a polyethylene bag and immediately transferred to Food and Nutrition Laboratory of the National Institute of Food Science 
and Technology for subsequent analysis. All reagents analytical grade were procured from Merck (Merck KGa A, Darmstadt, Germany).

Preparation of vegetable samples. The selected vegetables were rinsed with tap water in order to remove adhered soil, dust, dirt and other contaminants. The collected samples were reduced to an appropriate size by using hand knife. The reduced samples were kept in the dehydrator (Harvest Saver R-5A, commercial dehydrator systems Inc. Oregon, USA) at 55-60 ${ }^{\circ} \mathrm{C}$ till complete dryness. The dried vegetable samples were ground into fine powder using a household blender (WF-8814 West Point, France) and then stored in polyethylene bags. This dried sample was further used for determination of heavy metals.

Sample analysis. The heavy metals (cadmium, chromium, lead, nickel, zinc, manganese and iron) in vegetable samples were determined by following the procedure described by Huang et al. (2013). Briefly $5 \mathrm{~g}$ powdered sample was added into $100 \mathrm{~mL}$ Erlenmeyer flask. Concentrated $\mathrm{HNO}_{3}(10 \mathrm{~mL})$ and $\mathrm{HCLO}_{4}(5 \mathrm{~mL})$ were added to the sample followed by heating on a hot plate at $180{ }^{\circ} \mathrm{C}$ for $1.5 \mathrm{~h}$ till the volume was reduced to 1-2 $\mathrm{mL}$ and the samples become colorless. Finally, the sample was filtered into a clean volumetric flask and diluted with double deionized water. The solution was analyzed by mean of atomic absorption spectrometer (AA240, Varian Inc. Victoria, Australia) equipped with a graphite furnace for $\mathrm{Ni}, \mathrm{Cr}, \mathrm{Cd}$, and $\mathrm{Pb}$ content.

Validation of analytical method. Blank sample and certified reference material (CRM) was prepared using the aforementioned digestion procedure and then run to check the accuracy of the analytical procedure. The reference material GBW10011 was purchased from National Research Center for Certified Material, China (NRCCRM). Qualitative results were obtained and the recoveries for all metals were ranged $\mathrm{b} / \mathrm{w} 83.7-99.4 \%$.

Survey on vegetables consumption. A survey was performed, while collecting the samples. A selfadministered questioner was used to obtain information about vegetable consumption. Total 250 people both male and female with age limit of 18-50 years were invited to participate in this survey. Basic information age, body weight and daily consumption rate including species was gathered to evaluate the daily intake of metals and health risk assessment. Average body weight calculated was $63.5 \mathrm{Kg}$ and the consumption rate of each vegetable is presented in (Table 3 ).
Calculation. Basic descriptive test (mean, standard deviation) was calculated by using SPSS for window version 18.0 (SPSS Inc., Chicago).

Estimated daily intake of heavy metals. The estimated daily intakes of heavy metals were calculated by using their mean value in vegetable sample. To evaluate EDIM following formula was used;

$\mathrm{EDIM}=\mathrm{FIR} \times \mathrm{C}_{\mathrm{f}} \times \mathrm{Cm} / \mathrm{Bw}$

Here, FIR represent food ingestion rate, $\mathrm{C}_{\mathrm{f}}$ conversion factor (0.085) for conversion of fresh to dry weight, $\mathrm{Cm}$ represent heavy metal concentration and $\mathrm{Bw}$ mean average body weight.

Health risk index (HRI). Health risk index was calculated by using the formula proposed by USEPA (1998).

$\mathrm{HRI}=\mathrm{EDIM} / \mathrm{RfD}$

$\mathrm{R}_{\mathrm{f}} \mathrm{D}$ represents oral reference dose for each toxic heavy metal. The $\mathrm{R}_{\mathrm{f}} \mathrm{D}$ for different heavy metals set by $\mathrm{WHO} /$ FAO are as follows; 0.007, 1.5, 0.025, 8.25, 0.3, 0.02, and $0.14 \mathrm{mg} / \mathrm{Kg}$ for $\mathrm{Cd}, \mathrm{Cr}, \mathrm{Pb}, \mathrm{Fe}, \mathrm{Zn}, \mathrm{Ni}$, and $\mathrm{Mn}$, respectively. If the $\mathrm{HRI}>1$ then the exposed population likely to experienced significant health risk, if HRI < 1 then the population is considered as safe.

\section{Results and Discussion}

Metal concentrations in vegetables. Heavy metals have been widely known to adversely affect the nutritive value of agricultural goods on account of their lethal impact on a human being. Regulatory agencies such as Codex, EU, and FAO have identified the maximum residual levels (MRLs) of toxic metals and pesticides in human food in the WTO scenario. In Pakistan, the major apprehension is the non-judicial use of agrochemicals like fertilizers, pesticides and irrigation with sewage and industrial effluents especially in the Peri-Urban location of major cities. In the present study, the vegetables samples collected from Peri-Urban areas of Multan and Rawalpindi regions were analyzed for the determination of different heavy metals such as cadmium $(\mathrm{Cd})$, chromium $(\mathrm{Cr})$, lead $(\mathrm{Pb})$, nickel $(\mathrm{Ni})$, manganese $(\mathrm{Mn})$, iron $(\mathrm{Fe})$ and zinc $(\mathrm{Zn})$ that compared with their maximum residual limits (MRLs). The mean values of the heavy metals in selected vegetables procured from Rawalpindi region are summarised in 
(Table 1). Maximum and the minimum Cd contents in vegetable samples were found in pea $(1.865 \mathrm{mg} / \mathrm{Kg})$ and cauliflower $(0.467 \mathrm{mg} / \mathrm{Kg})$, respectively. Among Multan samples (Table 2) maximum Cd content was found in bitter gourd $(0.786 \mathrm{mg} / \mathrm{Kg})$ followed by okra (0.678), while the least content was observed in tomato $(0.123 \mathrm{mg} / \mathrm{Kg})$. Cd concentration in all vegetable samples exceeded the permissible limit $(0.05 \mathrm{mg} / \mathrm{Kg})$ as described by Joint FAO/WHO Expert Committee on Food Additive's Codex (2001). Rawalpindi samples were high in Cd content than Multan possibly because that site was close to the waste inclinator, which produces atmospheric pollution to the surrounding localities. Cadmium (Cd) being a serious accumulative body poison finds a way into the body through water, air, and food and cannot be removed by washing vegetables. Cadmium generally accumulates in liver and kidney Divrikli et al. (2003). In Pakistan, farmers are blindly using untreated wastewater for vegetable production especially in the Peri-Urban areas. High cadmium concentration in vegetables is attributed to the mechanism for its easy accumulation by plants Grant et al. (1998). In a previous study Naser et al. (2009) reported $\mathrm{Cd}$ concentration for tomato and cauliflower 3.83 and $3.67 \mathrm{mg} / \mathrm{Kg}$, respectively. Likewise, in another study, Khan et al. (2013) reported the very high concentration of $\mathrm{Cd}$ in vegetables i.e. cauliflower and tomato grown in Peri-Urban areas of Lahore Pakistan. Maximum Cd concentration $6.7 \mathrm{mg} / \mathrm{Kg}$ was found in cauliflower followed by tomato $6.1 \mathrm{mg} / \mathrm{Kg}$, respectively.
Another study reported $\mathrm{Cd}$ contents in onion, cucumber and tomato $0.97,0.64$ and $0.41 \mathrm{mg} / \mathrm{Kg}$, respectively Demirezen and Aksoy (2006).

In this study chromium $(\mathrm{Cr})$ content in different vegetables ranged from $(1.052-2.482 \mathrm{mg} / \mathrm{Kg})$ with the highest level in onion and the lowest in pea (1.052), respectively (Table 1). As shown in (Table 2) samples collected from Multan region showed a wide variation in the ranges of $\mathrm{Cr}$ content. The highest $\mathrm{Cr}$ content was found in cucumber $(5.637 \mathrm{mg} / \mathrm{Kg})$, while the lowest in round gourd $(0.955 \mathrm{mg} / \mathrm{Kg}$ ) (Table 2). Results revealed that $\mathrm{Cr}$ content was within the permissible limit (2.3 $\mathrm{mg} / \mathrm{Kg}$ ) among Rawalpindi samples, while $\mathrm{Cr}$ content in Multan samples was several folds higher than the permissible limit $(2.3 \mathrm{mg} / \mathrm{Kg}$ ) set by WHO/ FAO Codex (2001). This may be due to the difference in the texture of soil, $\mathrm{pH}$, cation exchange capacity, soil organic contents or due to wastewater irrigation. In another study Shaheen et al., 2016 reported low content of chromium $(0.2-1.11 \mathrm{mg} / \mathrm{Kg})$ in different vegetable samples grown in Bangladesh. Our results were higher to those reported by Rehman et al. (2017) and lower than to those reported by (Khan et al., 2015; Liu et al., 2005).

In this study lead $(\mathrm{Pb})$ content ranged from (3.04-5.64 $\mathrm{mg} / \mathrm{Kg}$ ) and (1.183-6.96 mg/Kg) among both regions (Table 1 and 2). The following decreasing order was found for Rawalpindi region pea $>$ cauliflower $>$ potato $>$ turnip $>$ cucumber $>$ tomato $>$ carrot. Among Multan

Table 1. Mean concentration $(\mathrm{mg} / \mathrm{Kg} \mathrm{dw})$ and standard deviation of heavy metals in the vegetable samples collected from Rawalpindi region.

\begin{tabular}{llllllll}
\hline \hline Vegetables & \multicolumn{7}{c}{ Heavy metal $(\mathrm{mg} / \mathrm{Kg})$} \\
\hline & $\mathrm{Cd}$ & $\mathrm{Cr}$ & $\mathrm{Pb}$ & $\mathrm{Ni}$ & $\mathrm{Mn}$ & $\mathrm{Fe}$ & $\mathrm{Zn}$ \\
\cline { 2 - 8 } $\begin{array}{l}\text { Fruity(n=36) } \\
\text { Cauliflower }\end{array}$ & $0.4678 \pm 0.180$ & $1.189 \pm 0.256$ & $5.002 \pm 0.473$ & $9.072 \pm 0.647$ & $24.715 \pm 2.903$ & $52.359 \pm 7.840$ & $21.944 \pm 7.003$ \\
& & & & & & & \\
Tomato & $1.0500 \pm 0.360$ & $2.459 \pm 0.494$ & $3.309 \pm 0.360$ & $7.086 \pm 0.596$ & $18.158 \pm 2.578$ & $52.231 \pm 16.654$ & $25.929 \pm 4.023$ \\
Cucumber & $1.1422 \pm 0.110$ & $1.282 \pm 0.514$ & $4.245 \pm 0.755$ & $9.106 \pm 0.379$ & $16.311 \pm 3.390$ & $73.941 \pm 28.149$ & $28.418 \pm 3.831$ \\
Pea & $1.8656 \pm 0.143$ & $1.053 \pm 0.131$ & $5.648 \pm 0.477$ & $3.658 \pm 0.216$ & $27.854 \pm 7.984$ & $64.576 \pm 11.341$ & $24.071 \pm 4.387$ \\
Rooty (n=36) & & & & & & & \\
Onion & $0.9578 \pm 0.130$ & $2.483 \pm 0.364$ & $4.202 \pm 0.951$ & $9.266 \pm 0.966$ & $15.526 \pm 5.409$ & $76.767 \pm 34.465$ & $16.641 \pm 3.340$ \\
Potato & $1.1111 \pm .072$ & $1.551 \pm 0.148$ & $4.973 \pm 0.263$ & $7.292 \pm 0.450$ & $8.333 \pm 1.108$ & $42.019 \pm 2.764$ & $20.447 \pm 4.332$ \\
Turnip & $1.3256 \pm .087$ & $1.634 \pm 0.149$ & $4.266 \pm 0.862$ & $5.286 \pm 0.282$ & $9.642 \pm 1.478$ & $37.512 \pm 3.390$ & $25.831 \pm 5.165$ \\
Carrot & $1.0967 \pm .046$ & $1.967 \pm 0.312$ & $3.045 \pm 1.110$ & $3.356 \pm 0.211$ & $19.728 \pm 2.305$ & $47.086 \pm 7.890$ & $24.824 \pm 5.132$ \\
MRL & & & & & & & \\
FAO/WHO & 0.05 & 2.3 & 0.1 & 10 & - & 465 & 60 \\
SEPAC & 0.2 & 0.5 & - & 10 & - & - & 100 \\
\hline \hline
\end{tabular}

$\mathrm{MRL}=$ Maximum Residual Limit $; \mathrm{dw}=$ dry weight; $\mathrm{n}=$ number of samples; SEPAC $=$ State environmental protection administration, China 
region variation in lead content was in the following order; round gourd $>$ potato $>$ cucumber $>$ bittergourd $>$ onion $>$ okra $>$ tomato $>$ cauliflower $>$ brinjal. Lead content in all vegetable samples were above than the maximum permissible level $(0.1 \mathrm{mg} / \mathrm{Kg})$ as recommended by FAO/WHO Codex (2001). High concentration of lead $(\mathrm{Pb})$ in these vegetables is attributed to pollutants in irrigation water and due to heavy traffic pollution. Parveen et al. (2003) also reported high concentration of lead in cucumber $(1.72 \mathrm{mg} / \mathrm{Kg})$ and tomatoes $(1.56 \mathrm{mg} / \mathrm{Kg})$, respectively and declare those vegetables unsafe for health. In another study Sharma et al. (2008) reported lead (Pb) concentration (1.56 $\mu \mathrm{g} / \mathrm{g})$ in cauliflower collected from different market sites of India. Present finding showed a higher concentration of lead $(\mathrm{Pb})$ than those reported by (Zhou et al., 2007).

In vegetable samples, the maximum and the minimum value of the nickel (Ni) were $9.071 \mathrm{mg} / \mathrm{Kg}$ in cauliflower and $3.355 \mathrm{mg} / \mathrm{Kg}$ in carrot, respectively (Table 1). Nickel content in Multan sample was in the range of 4.07-7.90 mg/Kg (Table 2). Nickel content in all vegetable samples was below than the permissible limit of $10 \mathrm{mg} / \mathrm{Kg}$ set by joint FAO/WHO Codex (2001). In a previous study Naser et al. (2009) reported highest contents of nickel ( $\mathrm{Ni}$ ) in tomato ranged from (2.03$4.95 \mu \mathrm{g} / \mathrm{g})$ followed by cauliflower $(1.69-4.44 \mu \mathrm{g} / \mathrm{g})$, respectively. Present result endorses the previous finding of Rehman et al. (2017) who reported nickel content in different vegetables ranging (1.83-7.69 $\mathrm{mg} / \mathrm{Kg})$. Present findings are also corresponding to the results of Yusuf et al. (2003).

The mean concentrations of manganese $(\mathrm{Mn})$ ranged from $(8.33-27.85 \mathrm{mg} / \mathrm{Kg})$ in the Rawalpindi samples. Highest concentration was found in pea $(27.85 \mathrm{mg} / \mathrm{Kg})$ followed by cauliflower $(24.69 \mathrm{mg} / \mathrm{Kg})$, carrot $(19.72$ $\mathrm{mg} / \mathrm{Kg}$ ), tomato $(18.15 \mathrm{mg} / \mathrm{Kg})$, cucumber $(16.31$ $\mathrm{mg} / \mathrm{Kg}$ ), onion (15.52), and turnip (9.64 $\mathrm{mg} / \mathrm{Kg}$ ). The lowest concentrations were found in potatoes $(8.33$ $\mathrm{mg} / \mathrm{Kg}$ ). The highest and lowest concentrations were found in bitter gourd $(45.56 \mathrm{mg} / \mathrm{Kg})$ and brinjal $(7.90$ $\mathrm{mg} / \mathrm{Kg}$ ), An essential element is Manganese (Mn). Plant requires manganese to perform metabolic processes but their excessive accumulation can harm the consumer Sharma et al. (2006).

Iron $(\mathrm{Fe})$ showed high concentration in vegetable samples. Among Rawalpindi samples, highest concentration was detected in onion $(76.765 \mathrm{mg} / \mathrm{Kg})$, while the least concentration was found in turnip 37.51 $\mathrm{mg} / \mathrm{Kg}$ (Table 1). Vegetable samples from Multan showed higher concentration ranged from 46.758$156.784 \mathrm{mg} / \mathrm{Kg}$ (Table 2). Iron act as a micronutrients, if present in trace amount. Excess of iron associated with many health implications. In the literature, very high concentration of iron $(364 \mu \mathrm{g} / \mathrm{g})$ in different vegetables was reported by Ali and Al- Qahtani (2012). Similarly Khan and colleagues reported high iron

Table 2. Mean concentration $(\mathrm{mg} / \mathrm{Kg} \mathrm{dw})$ and standard deviation of heavy metals in the vegetable samples collected from Multan region.

\begin{tabular}{|c|c|c|c|c|c|c|c|}
\hline \multirow[t]{2}{*}{ Vegetables } & \multicolumn{7}{|c|}{ Heavy metal (mg/Kg) } \\
\hline & $\mathrm{Cd}$ & $\mathrm{Cr}$ & $\mathrm{Pb}$ & $\mathrm{Ni}$ & $\mathrm{Mn}$ & $\mathrm{Fe}$ & $\mathrm{Zn}$ \\
\hline \multicolumn{8}{|l|}{ Fruity $(n=63)$} \\
\hline Cauliflower & $0.1289 \pm 0.089$ & $1.2088 \pm 0.476$ & $1.8422 \pm 0.507$ & $4.076 \pm 1.006$ & $12.725 \pm 1.350$ & $46.758 \pm 6.089$ & $27.653 \pm 2.750$ \\
\hline Tomato & $0.1233 \pm 0.049$ & $3.0533 \pm 0.369$ & $1.9589 \pm 0.169$ & $7.014 \pm 0.305$ & $12.299 \pm 1.415$ & $59.579 \pm 2.451$ & $16.543 \pm 6.118$ \\
\hline Cucumber & $0.1356 \pm 0.077$ & $5.6378 \pm 0.602$ & $5.8422 \pm 1.356$ & $6.984 \pm 2.387$ & $31.036 \pm 21.078$ & $91.253 \pm 24.010$ & $28.535 \pm 3.811$ \\
\hline Brinjal & $0.3611 \pm 0.106$ & $1.9556 \pm 0.417$ & $1.1833 \pm 0.315$ & $7.9045 \pm .101$ & $7.9045 \pm .101$ & $78.708 \pm 18.155$ & $20.569 \pm 2.252$ \\
\hline Round Gourd & $0.3322 \pm 0.225$ & $0.9556 \pm 0.201$ & $6.9678 \pm 0.5271$ & $6.0057 \pm 0.319$ & $17.796 \pm 1.771$ & $77.377 \pm 20.02$ & $28.074 \pm 6.444$ \\
\hline Bitter Gourd & $0.7867 \pm 0.126$ & $3.78 \pm 0.513$ & $4.6189 \pm 0.431$ & $7.7412 \pm 0.416$ & $45.566 \pm 6.178$ & $153.784 \pm 14.52$ & $24.212 \pm 7.556$ \\
\hline Okra & $0.6789 \pm 0.087$ & $1.6878 \pm 0.272$ & $2.7911 \pm 0.303$ & $4.1856 \pm 0.127$ & $32.296 \pm 3.3094$ & $121.298 \pm 7.211$ & $23.797 \pm 5.706$ \\
\hline \multicolumn{8}{|l|}{$\operatorname{Rooty}(n=18)$} \\
\hline Onion & $0.1267 \pm 0.04$ & $1.9411 \pm 0.340$ & $4.1656 \pm 0.411$ & $7.2767 \pm 0.589$ & $26.026 \pm 7.586$ & $135.445 \pm 7.859$ & $19.5 \pm 2.963$ \\
\hline Potato & $0.2356 \pm 0.067$ & $2.7956 \pm 0.370$ & $6.5211 \pm 0.464$ & $4.2122 \pm 0.320$ & $14.136 \pm 5.557$ & $58.642 \pm 9.142$ & $22.585 \pm 4.400$ \\
\hline \multicolumn{8}{|l|}{ MRL } \\
\hline $\mathrm{FAO} / \mathrm{WHO}$ & 0.05 & 2.3 & 0.1 & 10 & - & 465 & 60 \\
\hline SEPAC & 0.2 & 0.5 & - & 10 & - & - & 100 \\
\hline
\end{tabular}

$\mathrm{MRL}=$ Maximum Residual Limit $; \mathrm{dw}=$ dry weight; $\mathrm{n}=$ number of samples; SEPAC $=$ State Environmental protection Administration, China 
Table 3. Estimated daily intake of metals (EDIM) through consumption of different vegetables grown in both regions.

\begin{tabular}{|c|c|c|c|c|c|c|c|c|}
\hline \multirow[t]{2}{*}{ Vegetables } & \multirow{2}{*}{$\begin{array}{l}\text { Consumption } \\
\text { g/day/person }\end{array}$} & \multicolumn{7}{|c|}{ Estimated daily intake of metals (mg/day) } \\
\hline & & $\mathrm{Cd}$ & $\mathrm{Cr}$ & $\mathrm{Pb}$ & $\mathrm{Ni}$ & $\mathrm{Mn}$ & $\mathrm{Fe}$ & $\mathrm{Zn}$ \\
\hline Cauliflower(R) & 120 & 7.514E-05 & 0.000191 & 0.000804 & 0.001458 & 0.00397 & 0.008412 & 0.0035248 \\
\hline Cauliflower(M) & 120 & $2.071 \mathrm{E}-05$ & 0.000195 & 0.000296 & 0.000655 & 0.002044 & 0.007511 & 0.0044418 \\
\hline Tomato $(\mathrm{R})$ & 130 & 0.0001827 & 0.000428 & 0.000576 & 0.001234 & 0.001859 & 0.009089 & 0.004512 \\
\hline Tomato( M) & 130 & $2.146 \mathrm{E}-05$ & 0.000532 & 0.000341 & 0.001221 & 0.001259 & 0.010368 & 0.0028786 \\
\hline Cucumber (R) & 74 & 0.0001 & 0.000126 & 0.000421 & 0.000902 & 0.001616 & 0.007325 & 0.0028149 \\
\hline Cucumber (M) & 74 & 0.0000 & 0.000559 & 0.000579 & 0.000692 & 0.003074 & 0.009040 & 0.0028265 \\
\hline Pea & 120 & 0.0003 & 0.000170 & 0.000908 & 0.000588 & 0.004474 & 0.010373 & 0.0038665 \\
\hline Brinjil & 110 & 0.0001 & 0.000289 & 0.000175 & 0.001168 & 0.001167 & 0.011621 & $0.003036 \mathrm{C}$ \\
\hline Round gourd & 118 & $5.248 \mathrm{E}-05$ & 0.000151 & 0.001101 & 0.000949 & 0.002811 & 0.012222 & 0.0044343 \\
\hline Bitter gourd & 104 & 0.0001096 & 0.000527 & 0.000644 & 0.001078 & 0.006343 & 0.021409 & 0.0033705 \\
\hline Okra & 170 & 0.0001545 & 0.000385 & 0.000636 & 0.000953 & 0.007349 & 0.027603 & 0.0054152 \\
\hline Onion (R) & 90 & 0.0001154 & 0.000300 & 0.000507 & 0.001117 & 0.00187 & 0.009249 & 0.0020048 \\
\hline Onion (M) & 90 & $1.527 \mathrm{E}-05$ & 0.000234 & 0.000502 & 0.000877 & 0.003135 & 0.016318 & 0.0023492 \\
\hline Potato (R) & 86 & 0.0001280 & 0.000179 & 0.000751 & 0.000840 & 0.00097 & 0.004838 & 0.0023538 \\
\hline Potato (M) & 86 & $2.713 \mathrm{E}-05$ & 0.000322 & 0.000751 & 0.000485 & 0.001646 & 0.006751 & 0.0025999 \\
\hline Turnip & 86 & 0.0001527 & 0.000189 & 0.000492 & 0.000609 & 0.00111 & 0.004319 & 0.0029736 \\
\hline Carrot & 128 & 0.0001880 & 0.000337 & 0.000522 & 0.000575 & 0.00338 & 0.008068 & 0.0042534 \\
\hline \multirow{2}{*}{\multicolumn{2}{|c|}{$\begin{array}{l}\text { EDIM from all } \\
\text { vegetables }\end{array}$}} & 0.0017240 & 0.005107 & 0.009998 & 0.015393 & 0.0184507 & 0.184507 & 0.0576566 \\
\hline & & & 0.2 & 0.21 & 0.3 & $2-5$ & - & 60 \\
\hline MTDI0.021 & & & & & & & & \\
\hline
\end{tabular}

M = sample collected from Multan; $\mathrm{R}$ = Sample collected from Rawalpindi; $\mathrm{MTDI}=$ Maximum tolerable daily intake

contents $(73-190 \mathrm{mg} / \mathrm{Kg})$ in cauliflower and tomato, which is similar to the current finding of Khan et al. (2013). Farmer are not well trained in Pakistan and blindly use wastewater to irrigate vegetables and other crops without taking into account their consequences. Heavy metals accumulations is due to direct use of untreated wastewater. Furthermore, non-judicial applications, of agricultural practices imparts to food stuffs an alternative source of heavy metal.

Zinc $(\mathrm{Zn})$ concentration in vegetable samples varied in the range of $16.64-28.41 \mathrm{mg} / \mathrm{Kg}$ with least concentration in onion and maximum concentration in cucumber (Table 1). Among Multan samples, highest concentration was observed in cucumber $(28.53 \mathrm{mg} / \mathrm{Kg})$, whereas lowest concentration was detected in tomato (16.54 $\mathrm{mg} / \mathrm{Kg}$ ) (Table 2). All the vegetable samples were within the maximum permissible limit of $60 \mathrm{mg} / \mathrm{Kg}$ set by $\mathrm{FAO} / \mathrm{WHO}$. Zinc is most important and a vital trace component for higher plants and animals and also play a role in energy metabolism, transcription and translation due to the variety of enzyme systems (Meunier et al., 2005). In some soil, the higher amount of zinc is associated to human activities and it is potentially dangerous. Excessive contents in soil results in phytotoxicity and eventually enter to the food chain. Results obtained from the present study were similar to those obtained by Mohammad et al. (2003) who found $\mathrm{Zn}$ contents in cucumber $32.3 \mu \mathrm{g} / \mathrm{g}$ and 20.08 $\mathrm{mg} / \mathrm{Kg}$, respectively.

Estimated daily intake of heavy metals. Heavy metals are comon componeuts in the Earth's crust that are not degradable. There are several pathways of heavy metal exposure in our body. These enter our body through different routes like food, drinking water, and air and cause many serious effects even at very low concentration. The explantion behind the toxicity of heavy metals is that they are noncompetitive inhibitors for numerous enzymes Esposito et al. (2001). Table 3 summarizes the estimated daily intake of metals (EDIM) of seven metals $(\mathrm{Cd}, \mathrm{Cr}, \mathrm{Pb}, \mathrm{Ni}, \mathrm{Mn}, \mathrm{Fe}$, and $\mathrm{Zn}$ along with maximum tolerable daily intake (MTDI). EDIM were evaluated following the mean concentrations of each metal in each vegetable and the respective consumption rate among the masses. Iron $(\mathrm{Fe})$ showed highest daily intake 0.185 followed by $\mathrm{Zn}(0.058), \mathrm{Mn}$ (0.049), $\mathrm{Ni}(0.015), \mathrm{Pb}$ (0.009), $\mathrm{Cr}(0.0051)$, and $\mathrm{Cd}$ $(0.0018) \mathrm{mg} /$ day, respectively. It is obvious from the finding that the daily intake of all the metals was less than the respective MTDI. 
Table 4. Health risk assessment of heavy metals from consuming different vegetables grown in both regions.

\begin{tabular}{llllllll}
\hline \hline Vegetables & & & & \multicolumn{2}{l}{ Health risk index } & \\
& Cd & Cr & Pb & Ni & Zn & Fe & Mn \\
\hline Cauliflower(R) & $1.074 \mathrm{E}-05$ & $1.274 \mathrm{E}-07$ & $3.214 \mathrm{E}-05$ & $7.286 \mathrm{E}-05$ & $1.175 \mathrm{E}-05$ & $1.019 \mathrm{E}-06$ & $2.835 \mathrm{E}-05$ \\
Cauliflower (M) & $2.958 \mathrm{E}-06$ & $1.295 \mathrm{E}-07$ & $1.184 \mathrm{E}-05$ & $3.273 \mathrm{E}-05$ & $1.481 \mathrm{E}-05$ & $9.104 \mathrm{E}-07$ & $1.459 \mathrm{E}-05$ \\
Tomato (R) & $2.611 \mathrm{E}-05$ & $2.853 \mathrm{E}-07$ & $2.304 \mathrm{E}-05$ & $6.166 \mathrm{E}-05$ & $1.5041 \mathrm{E}-05$ & $1.102 \mathrm{E}-06$ & $1.327 \mathrm{E}-05$ \\
Tomato( M) & $3.066 \mathrm{E}-06$ & $3.543 \mathrm{E}-07$ & $1.364 \mathrm{E}-05$ & $6.103 \mathrm{E}-05$ & $9.596 \mathrm{E}-06$ & $1.257 \mathrm{E}-06$ & $8.992 \mathrm{E}-06$ \\
Cucumber (R) & $1.643 \mathrm{E}-05$ & $8.460 \mathrm{E}-08$ & $1.682 \mathrm{E}-05$ & $4.510 \mathrm{E}-05$ & $9.384 \mathrm{E}-06$ & $8.878 \mathrm{E}-07$ & $1.153 \mathrm{E}-05$ \\
Cucumber (M) & $1.919 \mathrm{E}-06$ & $3.724 \mathrm{E}-07$ & $2.315 \mathrm{E}-05$ & $3.9 \mathrm{E}-05$ & $9.422 \mathrm{E}-06$ & $1.096 \mathrm{E}-06$ & $2.195 \mathrm{E}-05$ \\
Pea & $4.282 \mathrm{E}-05$ & $1.127 \mathrm{E}-07$ & $3.629 \mathrm{E}-05$ & $2.938 \mathrm{E}-05$ & $1.289 \mathrm{E}-05$ & $1.258 \mathrm{E}-06$ & $3.195 \mathrm{E}-05$ \\
Brinjil & $7.596 \mathrm{E}-06$ & $1.925 \mathrm{E}-07$ & $6.989 \mathrm{E}-06$ & $5.836 \mathrm{E}-05$ & $1.013 \mathrm{E}-05$ & $1.409 \mathrm{E}-06$ & $8.336 \mathrm{E}-06$ \\
Round gourd & $7.496 \mathrm{E}-06$ & $1.007 \mathrm{E}-07$ & $4.403 \mathrm{E}-05$ & $4.744 \mathrm{E}-05$ & $1.479 \mathrm{E}-05$ & $1.482 \mathrm{E}-06$ & $2.007 \mathrm{E}-05$ \\
Bitter gourd & $1.565 \mathrm{E}-05$ & $3.509 \mathrm{E}-07$ & $2.573 \mathrm{E}-05$ & $5.389 \mathrm{E}-05$ & $1.124 \mathrm{E}-05$ & $2.595 \mathrm{E}-06$ & $4.530 \mathrm{E}-05$ \\
Okra & $2.207 \mathrm{E}-05$ & $2.561 \mathrm{E}-07$ & $2.545 \mathrm{E}-05$ & $4.763 \mathrm{E}-05$ & $1.806 \mathrm{E}-05$ & $3.346 \mathrm{E}-06$ & $5.249 \mathrm{E}-05$ \\
Onion (R) & $1.649 \mathrm{E}-05$ & $1.994 \mathrm{E}-07$ & $2.025 \mathrm{E}-05$ & $5.582 \mathrm{E}-05$ & $6.683 \mathrm{E}-06$ & $1.121 \mathrm{E}-06$ & $1.336 \mathrm{E}-05$ \\
Onion (M) & $2.181 \mathrm{E}-06$ & $1.559 \mathrm{E}-07$ & $2.008 \mathrm{E}-05$ & $4.389 \mathrm{E}-05$ & $7.831 \mathrm{E}-06$ & $1.978 \mathrm{E}-06$ & $2.239 \mathrm{E}-05$ \\
Potato (R) & $1.828 \mathrm{E}-05$ & $1.190 \mathrm{E}-07$ & $3.003 \mathrm{E}-05$ & $4.197 \mathrm{E}-05$ & $7.846 \mathrm{E}-06$ & $5.864 \mathrm{E}-07$ & $6.931 \mathrm{E}-06$ \\
Potato (M) & $3.875 \mathrm{E}-06$ & $2.146 \mathrm{E}-07$ & $3.003 \mathrm{E}-05$ & $2.425 \mathrm{E}-05$ & $8.667 \mathrm{E}-06$ & $8.183 \mathrm{E}-07$ & $1.176 \mathrm{E}-05$ \\
Turnip & $2.181 \mathrm{E}-05$ & $1.254 \mathrm{E}-07$ & $1.965 \mathrm{E}-05$ & $3.043 \mathrm{E}-05$ & $9.913 \mathrm{E}-06$ & $5.235 \mathrm{E}-07$ & $7.927 \mathrm{E}-06$ \\
Carrot & $2.685 \mathrm{E}-05$ & $2.247 \mathrm{E}-07$ & $2.087 \mathrm{E}-05$ & $2.873 \mathrm{E}-05$ & $1.418 \mathrm{E}-05$ & $9.779 \mathrm{E}-07$ & $2.414 \mathrm{E}-05$ \\
THRI & 0.000247 & $3.405 \mathrm{E}-06$ & 0.000399 & 0.000770 & 0.000193 & $2.237 \mathrm{E}-05$ & 0.000344 \\
\hline \hline
\end{tabular}

$\mathrm{M}=$ sample collected from Multan; $\mathrm{R}=$ Sample collected from Rawalpindi; THRI = Total health risk index

Assessment of health risk index (HRI). Health risks from the mass consumption of contaminated vegetables is evaluated and summarised in the (Table 4). The health risk index $<1$ considered as safe Zheng et al. (2007). Results showed that HRI of all the metals fell within the permissible limit $(<1)$ which indicates that exposed population due to the consumption of these vegetables. The following decreasing order was observed for heavy metals in all vegetable samples $\mathrm{NI}>\mathrm{Pb}>\mathrm{Mn}>\mathrm{Cd}>$ $\mathrm{Zn}>\mathrm{Cr}>\mathrm{Fe}$, respectively.

\section{Conclusion}

This study revealed the presence of heavy metals in selected vegetables grown in Peri-Urban areas of Punjab as well as estimated daily intake and the associated health risk by consuming these vegetables. Among both regions, a wide range of variation for different heavy metals in different vegetables were observed. Results revealed that cadmium $(\mathrm{Cd})$, and lead $(\mathrm{Pb})$ content was exceeding their maximum residual limits (MRLs) set by FAO/WHO. From the consumption perspective, EDIM and HRI of all metals were below than the permissible limit hence it is concluded that consumption of these vegetables poses no significant threat to the local population.

\section{Acknowledgement}

I would like to thanks Dr. Khalid Bashir Principle investigator of project Food Utilization Among Poor
Households in Peri-Urban Areas of North and South Punjab Pakistan sponsored by IFPRI for the provision of chemicals and standards.

Conflict of Interest. The authors declare no conflict of interest.

\section{References}

Ali, M.H.H., Al-Qahtani, K.M. 2012. Assessment of some heavy metals in vegetables, cereals and fruits in Saudi arabian markets. The Egyptian Journal of Aquatic Research, 38: 31-37. https://doi.org/10. 1016/j.ejar.2012.08.002

Demirezen, D., Aksoy, A. 2006. Heavy metal levels in vegetables in Turkey are within safe limits for $\mathrm{Cu}$, $\mathrm{Zn}$, Ni and exceeded for $\mathrm{Cd}$ and $\mathrm{Pb}$. Journal of Food Quality, 29: 252-265. https://doi.org/10.1111/j. 1745-4557.2006.00072.x

Divrikli, U., Saracoglu, S., Soylak, M., Elci, L. 2003. Determination of trace heavy metals contents of green vegetable samples from Kayseri-Turkey by flame atomic absorption spectrometry. Fresenius Environmental Bulletin, 12: 1123-1125.

Ensink, J.H., Mahmood, T., Vander Hoek, W., RaschidSally, L., Amerasinghe, F.P. 2004. A nationwide assessment of wastewater use in Pakistan: an obscure activity or a vitally important one. Water Policy, 6: 197-206. 
Esposito, A., Pagnanelli, F., Lodi, A., Solisio, C., Vegliò, F. 2001. Biosorption of heavy metals by Sphaerotilus natans: an equilibrium study at different $\mathrm{pH}$ and biomass concentrations. Hydrometallurgy, 60: 129-141. https://doi.org/10. 1016/S0304-386X(00)00195-X

FAO (Food and Agriculture Organization). 2002. FAO/WHO global forum of food safety regulators. Food and Agriculture Organization of the United Nation, Marrakech, Morroco.

FAO/WHO). Codex Alimentarius Commission. 2001.

Food Additives and Contaminants. Joint FAO/WHO Food Standards Program. ALINORM 01/12A, pp. 1e289. ftp://ftp.fao.org/Codex/Reports/Alinorm01/ al01_27e.pdf.

GOP (Government of Pakistan). 2013. Agricultural Statistics of Pakistan. Ministry of Food and Agriculture (Economic Wing), Govt. of Pakistan, Islamabad, Pakistan.

Grant, C.A., Buckley, W.T., Bailey, L.D., Selles, F. 1998. Cadmium accumulation in crops. Canadian Journal of Plant Science, 78: 1-17. https://doi.org/ 10.4141/P96-100

Haiyan, W., Stuanes, A. O. 2003. Heavy metal pollution in air, water, soil-plant system of Zhuzhou city, Hunan province, China. Water, Air, and Soil Pollution. 147: 79-107.

Huang, Z., Pan, X.D., Wu, P.G., Han, J.L., Chen, Q. 2013. Health risk assessment of heavy metals in rice to the population in Zhejiang, China. PLoS ONE, 8: 1-6. https://doi.org/10.1371/journal.pone. 0075007

Jimoh, F.O., Oladiji, A.T. 2005. Preliminary studies on Piliostigma thonningii seeds: proximate analysis, mineral composition and phytochemical screening. Africa Journal of Biotechnology, 4: 1439-1442. https://doi.org/10.4314/ajb.v4i12.71459

Khan, A., Javid, S., Muhmood, A., Mjeed, T., Niaz, A., Majeed, A. 2013. Heavy metal status of soil and vegetables grown on Peri-Urban area of Lahore district. Soil Science Society of Pakistan, 32: 4954. https://doi.org/10.4314/ajb.v5i10.42835

Khan, M.U., Malik, R.N., Muhammad, S., Ullah, F., Qadir, A. 2015. Health risk assessment of consumption of heavy metals in market food crops from sialkot and Gujranwala districts, Pakistan. Human and Ecological Risk Assessment: An International Journal, 21: 327-337. https://doi.org/ 10.1080/10807039.2014.913445

Khan, S., Cao, Q., Zheng, Y.M., Huang, Y.Z., Zhu, Y.G.
2008. Health risks of heavy metals in contaminated soils and food crops irrigated with wastewater in Beijing, China. Environmental Pollution, 152: 686692. https://doi.org/10.1016/j.envpol.2007.06.056

Liu, W.H., Zhao, J.Z., Ouyang, Z.Y., Söderlund, L., Liu, G.H. 2005. Impacts of sewage irrigation on heavy metal distribution and contamination in Beijing, China. Environment International, 31: 805-812. https://doi.org/10.1016/j.envint.2005. 05.042

Lock, K., Pomerleau, J., Causer, L., Altmann, D.R., McKee, M. 2005. The global burden of disease attributable to low consumption of fruit and vegetables: Implications for the global strategy on diet. Bulletin of the World Health Organization, 83: 100-108. https://doi.org//S0042-96862005000 200010

Mapanda, F., Mangwayana, E.N., Nyamangara, J., Giller, K.E. 2005. The effect of long-term irrigation using wastewater on heavy metal contents of soils under vegetables in Harare, Zimbabwe. Agriculture, Ecosystems and Environment, 107: 151-165. https:// doi.org/10.1016/j.agee.2004.11.005

Mapanda, F., Mangwayana, E.N., Nyamangara, J., Giller, K.E. 2007. Uptake of heavy metals by vegetables irrigated using wastewater and the subsequent risks in Harare, Zimbabwe. Physics and Chemistry of the Earth, Parts $A / B / C, 32: 1399$ 1405. https://doi.org/10.1016/j.pce.2007.07.046

Meunier, N., O’Connor, J.M., Maiani, G., Cashman, K.D., Secker, D.L., Ferry, M., Coudray, C. 2005. Importance of zinc in the elderly: the ZENITH study. European Journal of Clinical Nutrition, 59: 51-54. https://doi.org/10.1038/sj.ejcn.1602286

Mohamed, A.E., Rashed, M.N., Mofty, A. 2003. Assessment of essential and toxic elements in some kinds of vegetables. Ecotoxicology and Environmental Safety, 55: 251-260.

Muchuweti, M., Birkett, J.W., Chinyanga, E., Zvauya, R., Scrimshaw, M.D., Lester, J.N. 2006. Heavy metal content of vegetables irrigated with mixtures of wastewater and sewage sludge in Zimbabwe: Implications for human health. Agriculture, Ecosystems \& Environment, 112: 41-48. https://doi. org/10.1016/j.agee.2005.04.028

Murtaza, G., Ghafoor, A., Qadir, M. 2008. Accumulation and implications of cadmium, cobalt and manganese in soils and vegetables irrigated with city effluent. Journal of the Science of Food and Agriculture, 88: 100-107. https://doi.org/10.1002/jsfa.3052 
Murtaza, G., Ghafoor, A., Qadir, M., Owens, G., Aziz, M.A., Zia, M.H., Saifullah. 2010. Disposal and use of sewage on agricultural lands in Pakistan: $A$ Review. Pedosphere, 20: 23-34. https://doi.org/10. 1016/S1002-0160(09)60279-4

Naser, H.M., Shil, N.C., Mahmud, N.U., Rashid, M.H., Hossain, K.M. 2009. Lead, cadmium and nickel contents of vegetables grown in industrially polluted and non-polluted areas of Bangladesh. Bangladesh Journal of Agricultural Research, 34: 545-554. https://doi.org/10.3329/bjar.v34i4.5831

Parveen, Z., Khuhro, M.I., Rafiq, N. 2003. Market basket survey for lead, cadmium, copper, chromium, nickel, and zinc in fruits and vegetables. Bulletin of Environmental Contamination and Toxicology, 71: 1260-1264. https://doi.org/10.1007/s00128003-8640-4

Prashanth, L., Kattapagari, K.K., Chitturi, R.T., Baddam, B.R., Prasad, K.L. 2015. A review on role of essential trace elements in health and disease. Journal of Dr. NTR University of Health Sciences, 4: 75-85. https://doi.org/10.4103/2277-8632.158577

Raouf, A.M.S., Raheim A.R.M. 2016. Removal of heavy metals from industrial waste water by biomassbased materials: a review. Journal of Pollution Effects \& Control, 5: 1-13. https://doi.org/ 10.4172/ 2375-4397.1000180

Rehman, Z.U., Khan, S., Shah, M.T., Brusseau, M.L., Khan, S. A., Maiinhagu, J. 2017. Transfer of heavy metals from soils to vegetables and associated human health risk in selected sites in Pakistan. Pedosphere, 160: https://doi.org/10.1016/S10020160(17)60440-5

Shaheen, N., Irfan, N.M., Khan, I.N., Islam, S., Islam, M.S., Ahmed, M.K. 2016. Presence of heavy metals in fruits and vegetables: Health risk implications in Bangladesh. Chemosphere, 152: 431-438. https:// doi.org/10.1016/j.chemosphere.2016.02.060

Sharma, R.K., Agrawal, M., Marshall, F. 2006. Heavy metal contamination in vegetables grown in wastewater irrigated areas of Varanasi, India. Bulletin of Environmental Contamination and Toxicology, 77: 312-318. https://doi.org/10.1007/ s00128-006-1065-0

Sharma, R.K., Agrawal, M., Marshall, F.M. 2008. Heavy metal $(\mathrm{Cu}, \mathrm{Zn}, \mathrm{Cd}$ and $\mathrm{Pb})$ contamination of vegetables in urban India: A case study in Varanasi. Environmental Pollution, 154: 254-263. https://doi. org/10.1016/j.envpol.2007.10.010

US-EPA (United States Environmental Protection Agency). 2005. Guidelines for carcinogen risk assessment, EPA/630/P-03/001F, Risk Assessment Forum, and Washington, DC, USA.

US-EPA (US Environmental Protection Agency). 1998. arsenic, inorganic. integrated risk information system (IRIS). (CASRN 7440-38-2). Washington, DC, USA.

WHO (World Health Organization). 2011. Evaluation of certain food additive and contaminants (Section 5.2 Lead). World Health Organization Technical Report Series, 960: 162-177.

Wiinikka, H., Grönberg, C., Boman, C. 2013. Emissions of heavy metals during fixed-bed combustion of six biomass fuels. Energy \& Fuels, 27: 1073-1080. https://doi.org/10.1021/ef3011146

Wong, C.S.C., Li, X.D., Zhang, G., Qi, S.H., Peng, X.Z. 2003. Atmospheric deposition of heavy metals in the Pearl River Delta, China. Atmospheric Environment, 37: 767-776. https://doi.org/10.1016/ S1352-2310(02)00929-9

Yusuf, A.A., Arowolo, T.A., Bamgbose, O. 2003. Cadmium, copper and nickel levels in vegetables from industrial and residential areas of Lagos City, Nigeria. Food and Chemical Toxicology, 41: 375-378. https://doi.org/10.1016/S0278-6915(02)00223-5

Zakir, S.N., Ihsanullah, I., Shah, M.T., Iqbal. Z., Ahmad, A. 2009. Comparison of heavy and trace metals levels in soil of Peshawar basin at different time intervals. Journal of Chemical Society of Pakistan, 31: 246-256.

Zheng, N., Wang, Q., Zhang, X., Zheng, D., Zhang, Z., Zhang, S. 2007. Population health risk due to dietary intake of heavy metals in the industrial area of Huludao city, China. Science of the Total Environment, 387: 96-104. https://doi.org/10.1016/ j.scitotenv.2007.07.044

Zhou, Z.Y., Fan, Y.P., Wang, M.J. 2000. Heavy Metal contamination in vegetables and their control in China. Food Reviews International, 16: 239-255. https://doi.org/10.1081/FRI-100100288 